\title{
PERAN POLA ASUH OTORITER TERHADAP KEMATANGAN EMOSI YANG DIMODERATORI OLEH KESABARAN
}

\author{
Subhan El Hafiz, Abul A'la Almaududi \\ Fakultas Psikologi Universitas Muhammadiyah Prof. DR. HAMKA \\ J1. Limau II, Kebayoran Baru, Jakarta Selatan \\ subhanhafiz@uhamka.ac.id
}

\begin{abstract}
Authoritarian Parenting style often judged as disturbing parenting style for development of the children. However, some of research shown inconsistency which is the parenting style also could give positive impact or have no effect. The purpose of this research was to exlpore the role of authoritarian parenting style to the development of the emotional maturity that expected to be moderated by patience competency. Participants of this research were 200 teenagers, 119 female and 81 male, who are study in Senior High School in Jakarta. Data collected by Patience Competency questionnaire, Emotional Maturity questionnaire and Parental Authority Questionnaire (PAQ). Data was analyzed through a moderator analysis. The result showed that the patience competency does not significat play as moderator variable to the authoritarian parenting style and teenager's emotional maturity. Futher analysis has proven that authoritarian parenting style and patience competency that was conducted by mother might gave positive impact to teenager's emotional maturity.
\end{abstract}

Keywords: authoritarian parenting style, emotional maturity, patience

\begin{abstract}
Abstrak
Pola asuh otoriter seringkali dianggap sebagai pola asuh yang bisa mengganggu perkembangan anak. Beberapa fakta penelitian menunjukkan hasil yang tidak konsisten, pola asuh otoriter berdampak positif atau tidak ada berdampak terhadap perkembangan anak. Penelitian ini bertujuan untuk mengetahui peran pola asuh otoriter terhadap kematangan emosi anak dengan harapan kompetensi kesabaran dapat berperan sebagai variabel moderator. Subjek penelitian adalah remaja sebanyak 200 orang yang terdiri dari 119 orang perempuan dan 81 orang laki-laki yang bersekolah di Jakarta. Data dikumpulkan menggunakan instrument kuisioner Kompetensi Kesabaran (KK), Kematangan Emosi (KE), dan Parental Authority Questionnaire (PAQ). Data dianalisa menggunakan analisa moderator. Hasil penelitian tidak menunjukkan peran kesabaran sebagai moderator terhadap kematangan emosi. Analisa lebih lanjut menunjukkan bahwa kesabaran dan pola asuh ibu yang otoriter terbukti memberi dampak positif terhadap kematangan emosi anak.
\end{abstract}

Kata Kunci: kematangan emosi, kesabaran, pola asuh otoriter 


\section{Pendahuluan}

Baumrind (1966) mengelompokkan pola asuh orangtua ke dalam tiga kategori yaitu pola asuh otoriter, demokratis, dan permisif. Pola asuh otoriter adalah pola asuh yang memberikan kesempatan pada anak untuk menentukan pilihannya dalam batas yang sudah ditentukan oleh orang tua. Pola asuh otoriter cenderung menentukan apa yang harus dilakukan atau dipilih anak adalah apa yang terbaik menurut orangtuanya. Pola asuh permisif cenderung memberi kebebasan kepada anak untuk menentukan apa yang terbaik bagi dirinya (Baumrind, 1968,1991). Penelitianpenelitian sebelumnya telah dilakukan untuk mengungkap dampak tiap pola asuh terhadap perkembangan anak, menyimpulkan bahwa pola asuh yang baik untuk perkembangan anak adalah pola asuh demokratis atau autoritatif, diantaranya penelitian yang dilakukan oleh Baumrind (1991), Darling \& Steinberg (1993), dan Chao (2001). Hasil penelitian mengenai dampak dua pola asuh lainnya yaitu pola asuh demokratis dan pola asuh permisif dan perkembangan anak menunjukkan hubungan yang umumnya tidak konsisten. Hasil penelitian yang dilakukan oleh Baumrind, 1991; Darling \& Steinberg, 1993 membuktikan bahwa terdapat hubungan negative antara dua pola asuh tersebut dengan perkembangan anak. Penelitian lain yang dilakukan oleh Blissett \& Haycraft, 2008; Chao, 1994) menunjukkan hasil sebaliknya, yaitu dua pola asuh tersebut memberikan manfaat yang positif terhadap perkembangan anak

Menurut Baumrind (1968) pola asuh otoriter masih bisa diterapkan untuk anak usia awal namun tidak lagi cocok jika diterapkan kepada anak yang sudah memasuki usia remaja. Pola asuh otoriter yang menggunakan kekuasaan untuk melegitimasi peraturan dari orangtua cenderung tidak cocok pada masa perkembangan remaja dimana anak remaja sudah memiliki kemampuan yang lebih matang dibandingkan masa kanak-kanak. Adapun penggunaan kekuasaan orangtua kepada anak remaja harus diimbangi dengan upaya memberikan penjelasan terkait dengan alasan dari peraturan tersebut.

Penerapan pola asuh otoriter oleh orangtua dengan mengontrol perilaku anak berdasarkan standar yang sudah ditetapkan oleh orangtua biasanya didorong oleh motivasi ideologi. Pola asuh ini cenderung mengontrol anak sebagaimana yang Tuhan harapkan terhadap anak. Hal inilah yang menyebabkan orang tua yang menjalankan pola asuh otoriter tidak memberi ruang pada anak untuk menegosiasikan peraturan karena aturan tersebut dianggap pedoman dari Tuhan (Baumrind, 1996)

Fakta penelitian terkait pola asuh otoriter ternyata tidak selalu konsisten. Beberapa penelitian justru menunjukkan bahwa pola asuh otoriter tidak berdampak terhadap perkembangan anak, baik positif atau negatif. Begitu juga fakta penelitian lain yang justru menunjukkan sebaliknya, yaitu pola asuh otoriter atau pola asuh yang dilakukan oleh orang tua yang diasumsikan otoriter ternyata memiliki dampak positif terhadap perkembangan anak (Blissett \& Haycraft, 2008; Chao, 1994; Steinberg, Lamborn, Darling, Mounts, \& Dornbusch, 1994).

Penelitian Steinberg, dkk (1994) membuktikan bahwa pola asuh demokratis menunjukkan dampak yang lebih baik bagi perkembangan anak dibanding pola asuh lainnya, yaitu otoriter dan neglected. Namun demikian, analisa post hoc menunjukkan bahwa kesimpulan umum tersebut tidak otomatis menjadikan pola asuh otoriter selalu berdampak negatif. Pada aspekaspek tertentu, pola asuh otoriter bahkan 
memberikan dampak yang sama positifnya dengan pola asuh demokratis.

Penelitian yang dilakukan di China justru menunjukkan fakta sebaliknya, yaitu pola asuh otoriter memberi dampak yang positif terhadap perkembangan anak. Chao (2001) mengatakan bahwa pola asuh otoriter berdampak negatif pada anak dari keluarga Eropa-Amerika namun pola asuh ini justru memberi dampak positif pada keluarga Cina-Amerika. Dalam artikelnya yang lain, Chao (1994, 2000) berkeyakinan bahwa pendekatan dari orangtua, terutama ibu, memberi dampak yang lebih positif terhadap perkembangan anak apabila diasuh dengan pola asuh otoriter.

Inkonsistensi hasil penelitian terkait pola asuh otoriter ini menjadi dasar bahwa dibutuhkan variabel tertentu yang dapat menerangkan efek dari pola asuh otoriter terhadap perkembangan anak. Variabel ini akan dapat menjelaskan bahwa dampak negatif atau positif dari pola asuh otoriter tergantung kondisi variabel yang menjadi perantaranya. Variabel yang diharapkan menjadi variabel moderator terkait pola asuh otoriter dan dampak pada perkembangan anak adalah kesabaran, hal ini mengacu pada penelitian pada remaja yang menunjukkan adanya peran kesabaran sebagai mediator dari pengaruh yang positif antara religiusitas dan kemampuan negosiasi konflik integratif (El Hafiz \& Nuramalina, 2015).

Kesabaran didefisikan sebagai kemampuan menahan emosi, pikiran, perkataan, dan perilaku yang dilakukan dengan tujuan kebaikan serta tidak melanggar aturan. Konsep kesabaran merupakan implementasi nilai sabar dalam Islam yang dikonstruk menggunakan metode analisa tafsir (El Hafiz, Mundzir, Pratiwi, Rozi, 2013). Dudley (2003) menjelaskan sabar (patience) sebagai sesuatu yang berlawanan dengan ketidaksabaran (impatience) namun bukan sebagai konstruk yang berdiri sendiri sebagaimana konstruk psikologi yang lain. Menurut Schnitker (2010) yaitu kecenderungan untuk menunggu dengan tenang dalam menghadapi frustrasi, kesulitan, atau penderitaan. Konsep kesabaran sudah lama dianggap sebagai karakter positif dan aspek penting dalam kesejahteraan seseorang (well-being). Walaupun demikian, penelitian tentang peran kesabaran masih sangat minim.

Menurut El Hafiz dkk. (2013) kesabaran terdiri dari tiga unsur utama, yaitu menahan, bertujuan kebaikan, dan taat aturan. Menahan dilakukan sebagai respon awal dimana individu akan menahan emosi, pikiran, perkataan, maupun perilakunya baik dalam kondisi sedih maupun senang selama hal itu diyakini sebagai hal yang baik. Proses menahan ini juga dilakukan sebagai proses yang aktif, artinya menahan perkataan, misalnya, bukan karena larangan atau tekanan tapi karena pilihan untuk menahan perkataan tersebut jika kata yang akan diucapkan akan lebih baik apabila tidak disampaikan pada saat itu.

Konstruk kesabaran ini dibangun dari kajian tafsir terhadap ayat yang memuat kata "Sabar" dalam kitab suci umat Islam. Secara khusus, metode analisa tafsir ini melakukan analisa terhadap tafsir al Misbah yang dilakukan oleh Quraish Shihab. Metode Analisa Tafsir merupakan metode untuk membangun konstruk psikologi terhadap konsep-konsep agama yang diajarkan dalam kitab suci (Pratiwi \& El Hafiz, 2015).

Kesabaran memiliki beberapa dimensi yang dapat menentukan tinggi rendahnya kesabaran seseorang. Dimensi ini berbeda dengan unsur kesabaran sebagaimana yang dijelaskan sebelumnya. Dimensi sabar dapat menentukan apakah kesabaran yang dijalankan orang tersebut tinggi atau rendah, sedangkan unsur kesabaran berfungsi untuk 
menentukan apakah menahan seseorang termasuk dalam kesabaran atau tidak. Dimensi kesabaran terdiri dari optimis, pantang menyerah, konsisten, tidak mengeluh, memaafkan, dan mencari ilmu untuk mendapatkan alternatif solusi (El Hafiz, dkk., 2013). Keenam dimensi ini yang menjadi indikator tinggi atau rendahnya kesabaran seseorang. Semakin tinggi kesabaran seseorang maka akan semakin baik pelaksanaan dari keenam dimensi tersebut dan sebaliknya. Kekurangan salah satu dimensi kesabaran ini tidak menjadikan individu menjadi tidak memiliki kesabaran namun menurunkan tingkat kesabaran.

Kematangan emosi merupakan salah satu komponen utama untuk menilai keberhasilan menghadapi gejolak masa remaja karena kematangan emosi yang paling baik adalah memahami berbagai kondisi emosi dan akibatnya namun tetap bisa otonom dalam mengambil keputusan dengan tidak terlalu terpengaruh oleh emosinya (Kapri \& Rani, 2014). Dengan demikian, kematangan emosi juga menjadi dasar untuk menilai bahwa seseorang sudah memasuki periode masa dewasa.

Menurut Kapri \& Rani (2014) level kematangan emosi ada 6 (enam) dimana level terendah adalah tanggungjawab emosional dasar (basic emotional responsibility) dan paling tinggi adalah kemandirian emosi (emotional detachment). Pada level pertama, tanggungjawab emosional dasar, individu harus menyadari untuk menerima emosinya dengan tidak menyalahkan aspek eksternal. Pada level paling tinggi, individu dapat tetap mengambil keputusan dengan tepat tanpa pengaruh dari kondisi emosinya pada saat itu, baik emosi positif maupun emosi negatif.

Level kematangan emosi yang berada diantara keduanya adalah kejujuran emosional (emotional honesty) yaitu kondisi dimana individu memahami dan menerima kondisi emosinya. Pada level selanjutnya adalah keterbukaan emosi (emotional openness) dimana individu dapat berbagi perasaannya dengan sikap yang tepat. Level yang lebih tinggi adalah asertifitas emosi (Emotional Assertiveness), individu menghargai dan mengeksperesikan emosi untuk menerima kebutuhan dan keinginan berbagai kondisi emosi. Satu level dibawah level tertinggi adalah pemahaman emosional (Emotional Understanding). Pada tahap ini individu dapat memahami sebab akibat dari emosi yang bertanggung jawab dan sebaliknya serta segala aspek dalam dirinya yang berkaitan dengan reaksi emosi tersebut (Kapri \& Rani, 2014).

Konsep yang juga relevan dengan kematangan emosi adalah diferensiasi emosi (emotional differentiation) yaitu kemampuan untuk memisahkan pikiran dan perasaan dan dapat memilih untuk dibimbing oleh intelektual atau emosional dalam pengambilan keputusan (Licht \& Chabot, 2006). Kapri \& Rani (2014) level terteinggi dari kematangan emosi adalah kemampuan untuk tidak dikendalikan oleh emosi dalam pengambilan keputusan.

Kesabaran dapat menjadi mediator pola asuh otoriter terhadap kematangan emosi individu karena pola asuh yang berasal dari orang tua tidak akan serta merta mengubah kondisi psikologis anak apabila tidak melalui penilaian anak terhadap perlakukan orangtua tersebut. Kemampuan anak dalam menilai perlakuan orangtua terhadap dirinya juga disumbang oleh tingkat kesabaran anak tersebut. Anak yang memiliki kemampuan kesabaran yang baik diharapkan akan mampu menilai perlakuan orangtua pada dirinya, walaupun dalam bentuk pola asuh otoriter, sebagai sesuatu yang baik dan hal itu justru akan menyebabkan anak semakin matang emosinya. 
Baumrind (1966) juga menjelaskan bahwa pola asuh otoriter bukanlah kondisi yang membuat anak dipaksa melakukan sesuatu tanpa tujuan atau alasan yang jelas. Pola asuh otoriter merupakan pola asuh orangtua yang menempatkan diri sebagai orang yang paling mengerti kebutuhan anaknya sehingga dirinya merasa pantas untuk memaksakan peraturan tertentu pada anak untuk dijalankan. Pada beberapa aspek, hal ini wajar karena orang tua memang memiliki lebih banyak pengalaman daripada anak sehingga mencoba memaksakan peraturan pada anak.

Salah satu penelitian terkait pola asuh menunjukkan bahwa perkembangan anak menjadi lebih positif konsep dirinya dalam bidang akademik jika orang tua menjalankan pola asuh otoriter (Steinberg, dkk. 1994). Penelitian ini juga secara khusus menjelaskan bahwa pola asuh jika dilihat dari aspek etnis, maka pola asuh yang biasa dijalankan dalam etnis afro-amerika tidak berpengaruh sama sekali dengan konsep diri anak dalam bidang akademis. Hasil lain dari penelitian Steinberg, dkk. (1994) juga menunjukkan bahwa pola asuh demokratis dan pola asuh otoriter sama-sama memiliki dampak yang positif terhadap gangguan pada masa remaja seperti alkohol dan narkoba.

Penelitian Chao (1994) menunjukkan bahwa pola asuh otoriter yang dijalankan di China memberi dampak positif terhadap perkembangan anak dan hal itu lebih banyak disebabkan karena keberhasilan ibu dalam mengajarkan ideologi pada anak. Sebagaimana yang dijelaskan oleh Baumrind (1996) terkait pola asuh otoriter yaitu orang tua menjalankan pola asuh tersebut dalam rangka memenuhi tuntutan ideologi dimana orangtua sedang menerapkan aturan yang merepresentasikan aturan Tuhan maka pola asuh otoriter menjadi tepat dalam konteks ini. Kesabaran yang diyakini secara ideologi bahwa individu yang menahan emosi, pikiran, perkataan, atau perilaku untuk tujuan yang baik adalah kebaikan maka besar kemungkinan juga mampu menerima pola asuh otoriter ini.

Beberapa penelitian yang menunjukkan pola asuh otoriter bermanfaat terhadap perkembangan anak (Steinberg, dkk., 1994; Chao, 1994; 2000; 2001) jelas menunjukkan bahwa pola asuh ini berdampak secara relatif terkait dengan pada budaya. Pada budaya Eropa dan Amerika pola asuh otoriter cenderung berdampak negatif, sedangkan pada budaya Asia pola asuh otoriter lebih banyak berdampak positif. Lain halnya dengan budaya Afrika yang tidak terlihat hubungan antara pola asuh otoriter terhadap perkembangan anak.

Kesabaran yang merupakan implementasi nilai sabar besar kemungkinan lebih banyak diajarkan pada budaya Asia. Hal ini sebagaimana dijelaskan oleh Schwartz (2006) bahwa negara-negara asia lebih menekankan pada nilai-nilai yang berorientasi pada lingkungan sekitar/ masyarakat (embeddedness) daripada nilai yang berorientasi pada diri sendiri (autonomy). Berdasarkan penjelasan ini dapat dipahami bahwa kesabaran yang merupakan implementasi nilai Sabar secara umum lebih berorietasi keharmonisan sosial daripada pemenuhan kebutuhan diri sendiri karena dalam kesabaran seseorang dituntut untuk menahan pemenuhan kebutuhan dirinya dalam menjaga relasinya dengan orang sekitar dan dia tetap meyakini bahwa perilaku menahan tersebut lebih baik daripada bersegera memenuhi kebutuhannya.

Walaupun secara khusus perlu dikaji perbedaan nilai sabar dalam budaya yang menekankan pada komunal dan budaya yang menekankan pada personal, namun penjelasan Schwartz (2006) dapat menjadi acuan bahwa dalam budaya timur, Asia, 
umumnya kesabaran akan lebih dimaknai sebagai nilai yang bersifat embeddedness daripada nilai yang bersifat autonomy. Dengan demikian, sabar menjadi salah satu nilai yang besar kemungkinan selalu diajarkan dalam masyarakat budaya Asia daripada budaya Eropa dan Amerika.

Nisbett, Peng, Choi, \& Norenzayan (2001) menjelaskan nilai sabar dalam budaya Asia akan lebih relevan dibanding budaya Eropa dan Amerika. Penelitian tersebut menjelaskan bahwa dalam kultur Asia, terutama Asia Timur, individu lebih banyak menggunakan model berpikir yang holistik, yaitu melihat sebuah masalah dari setiap aspek dan mempertimbangkan berbagai akibat pada masing-masing aspek tersebut. Secara khusus, masyarakat Asia Timur lebih sedikit menggunakan model berfikir kategorisasi, logika formal, dan argumentasi dialektika.

Sebagaimana konsep kesabaran yang dijelaskan oleh El Hafiz dkk (2013) bahwa konsep ini menuntut individu untuk menahan dirinya namun tetap memperhatikan lingkungan sekitar, misalnya taat aturan dan memaafkan. Kesabaran juga dapat dilakukan karena memperhatikan kebutuhan orang lain sehingga individu tersebut menahan dirinya, misalnya menahan diri untuk tidak makan di tempat umum agar orang lain tidak merasa terganggu dengan perilakunya. Hal ini menunjukkan bahwa kesabaran kemungkinan besar banyak diimplementasikan dalam konsteks budaya Asia sebagaimana penjelasan Nisbett, dkk (2001) terhadap model berpikir masyarakat Timur dan Barat.

Berdasarkan penjelasan di atas, hipotesa dalam penelitian ini adalah pola asuh otoriter akan mempengaruhi kematangan emosi remaja apabila dimoderatori oleh kesabaran. Individu yang memiliki tingkat kesabaran tinggi, pola asuh otoriter orangtua akan meningkatkan kematangan emosinya. Pada individu dengan kesabaran rendah, pola asuh otoriter orangtua akan menurunkan tingkat kematangan emosinya.

\section{Metode Penelitian}

Subjek penelitian sebanyak 200 orang remaja, terdiri dari 119 orang perempuan dan 81 orang laki-laki yang bersekolah pada tingkat Sekolah Lanjutan Tingkat Atas (SLTA disalah satu SLTA di Jakarta. Pemilihan subjek dilakukan secara acak dengan model cluster random sampling yaitu menentukan sample berdasarkan unit/ element yang menjadi sample (Neuman, 2000). Cluster yang dijadikan sebagai unit untuk sampling pada penelitian ini adalah tingkat kelas, yang terdiri dari kelas sepuluh, kelas sebelas, dan kelas dua belas. Berdasarkan cluster tersebut, maka kelas yang dijadikan subjek adalah kelas 10-12 yang tiap tingkat dipilih dua kelas yang menjadi samplenya dan instrumen penelitian disebarkan pada seluruh siswa di kelas tersebut.

Instrumen penelitian ini terdiri dari instrumen Kuisioner Kompetensi Kesabaran dari El Hafiz, dkk. (2013), Parental Authority Questionnaire (PAQ) dari Buri (1991) dan Chabot Emotional Differentiation (CED) Scale dari Licht \& Chabot (2006). Instrumen Kompetensi Kesabaran (KK) disusun oleh El Hafiz, dkk (2013) yang terdiri dari 20 (dua puluh) aitem. Namun aitem yang diskor hanya 13 (tiga belas) sebagaimana hasil analisa instrumen yang sudah dilakukan pada penelitian sebelumnya. Selain tiga aitem yang tidak diskor sebagai pengecoh, empat aitem lain yang tidak diskor merupakan bagian untuk menentukan sabar atau tidaknya seseorang, sedangkan bagian yang di skor adalah bagian yang menentukan tinggi rendahnya kesabaran seseorang El 
Hafiz, dkk (2012).

Instrumen Pola Asuh Otoriter penelitian ini berasal dari PAQ yang disusun oleh Buri (1991) terdiri mengukur tiga pola asuh berdasarkan persepsi anak terhadap pola asuh orangtuanya yang terdiri dari 30 (tiga puluh) aitem. Masing-masing pola asuh terdiri dari 10 (sepuluh) aitem yang dalam penelitian ini hanya diskor sepuluh aitem yang mengukur pola asuh otoriter karena sesuai dengan tujuan penelitian. Tiap pola asuh kemudian dibagi ke dalam pola asuh ayah dan pola asuh ibu, sehingga secara keseluruhan terdapat 20 (dua puluh) aitem pola asuh otoriter karena menurut Buri pola asuh ayah maupun pola asuh ibu dapat dipisah masing-masing perannya terhadap perkembangan anak.

Instrumen Kematangan Emosi (KE). Instrumen untuk mengukur kematangan (PAO). Instrumen pola asuh otoriter dalam

emosi menggunakan diadaptasi dari CED karena menurut teori Bowen (1978 dalam Licht \& Chabot, 2006) kemampuan melakukan diferensiasi emosi merupakan konsep yang paling kritis dalam kematangan perkembangan individu. Dengan demikian, individu yang memiliki kemampuan diferensiasi emosi baik diasumsikan memiliki kematangan emosi yang juga baik.

Berdasarkan hasil analisa data terhadap instrument penelitian, terlihat bahwa setiap instrument penelitian cukup reliabel sebagai alat pengumpul data dengan nilai reliabilitas $\alpha$ cronbach, 0.646 untuk KE, 0.686 untuk KK, 0.723 untuk PAO ibu, dan 0.742 untuk PAO ayah. Hal ini menunjukkan pada instrumen pengumpulan data dapat digunakan dalam penelitian ini.

\section{Hasil dan Pembahasan}

Tabel 1

Analisa Instrumen Penelitian

\begin{tabular}{llllccc}
\hline & KE & PAO Ayah & PAO Ibu & $\boldsymbol{\alpha}$ & Rata-rata & SD \\
\hline KE & - & & & 0.646 & 74.85 & 10.25 \\
PAO Ayah & -0.122 & - & & 0.742 & 41.20 & 9.63 \\
PAO Ibu & -0.017 & $0.611^{* * *}$ & - & 0.723 & 41.80 & 9.32 \\
KK & $0.402 * * *$ & 0.024 & -0.062 & 0.686 & 72.84 & 7.95 \\
\hline Catatan
\end{tabular}

Catatan:

- $\quad * * * \alpha<0.001, * * \alpha<0.01, * \alpha<0.05$

- KE: Kematangan Emosi, PAO: Pola Asuh Otoriter, KK: Kompetensi Kesabatan, SD: Standar Deviasi

Berdasarkan hasil analisa data menjelaskan bahwa pola asuh otoriter tidak dapat diketahui bahwa kematangan emosi tidak memiliki hubungan yang signifikan dengan pola asuh otoriter orangtua, baik ayah maupun ibu. Hal ini menujukkan bahwa asumsi pola asuh otoriter akan berdampak negatif pada perkembangan kematangan emosi remaja tidak terbukti. Data awal ini sesuai dengan penelitian yang selalu berdampak negatif, terutama untuk anak yang berasal dari Asia karena adanya perbedaan nilai budaya (lih. Schwartz, 2006; Steinberg, dkk., 1994; Chao, 1994; 2000; 2001)

Sebelum melakukan analisa moderator untuk pengujian hipotesa penelitian, maka terlebih dahulu dipastikan bahwa hubungan 
antar variabel memenuhi persyaratan untuk dilakukan uji moderator. Salah satu syarat untuk dilakukan uji moderator adalah variabel independen tidak berkorelasi dengan varibel dependen. Dari data korelasi didapat hasil bahwa korelasi PAO Ayah maupun PAO Ibu tidak signifikan dengan nilai $\alpha>0.05$ sebagaimana yang diharapkan.

Hasil analisis menujukkan bahwa terdapat hubungan positif yang signifikan antara kompetensi kesabaran dan kematangan emosi $(0.402, \alpha<0.001)$, hal ini menunjukkan bahwa kesabaran diharapkan dapat menjadi variabel moderator dari pola asuh otoriter orangtua terhadap kematangan emosi. Dasar untuk melakukan analisa moderator terhadap korelasi tersebut cukup kuat karena diharapkan sumbangan dari kesabaran dapat mempengaruhi dampak dari pola asuh otoriter orangtua terhadap perkembangan kematangan emosi anak yang akan dijelaskan pada hasil analisa moderator pada tahap berikutnya.

Berdasarkan hasil analisa data penelitian, baik pada dampak pola asuh ayah terhadap kematangan emosi, maupun pola asuh ibu terhadap kematangan emosi anak terbukti berpengaruh apabila terdapat kompetensi kesabaran pada diri anak tersebut. Namun demikian jika melihat pada interaksi antara kesabaran dengan pola asuh otoriter orangtua, ayah maupun ibu, kesabaran tidak bisa menjadi variabel moderator terhadap pola asuh otoriter orangtua terhadap kematangan emosi (PAO Ayah x KK, $\alpha>0.2$ dan PAO Ibu x KK $\alpha>0.2$ ).

Walaupun hipotesa moderator dari kesabaran tidak terbukti signifikan namun berdasarkan analisa dapat dilihat sumbangan yang signifikan dari pola asuh orangtua terhadap kematangan emosi. Kesabaran memberi pengaruh positif signifikan terhadap kematangan emosi apabila dilihat dari pola asuh otoriter ayah (PAO Ayah, B=-
$0.140, \alpha<0.05$ dan KK B=0.522, $\alpha<0.001)$. Berdasarkan hasil analisa regresi linier, model ini cocok untuk mendeskripsikan bahwa pola asuh ayah secara bersama-sama berinteraksi dengan kesabaran anak akan mempengaruhi kematangan emosi.

Model yang sama juga cukup cocok untuk pola asuh otoriter dari ibu, namun demikian sumbangan pola asuh ibu dalam model kedua dengan $\mathrm{B}=0.008$ ternyata tidak cukup signifikan $(\alpha>0.2)$. Individu dengan kesabaran yang baik, maka pola asuh otoriter ibu tidak terlalu signifikan mempengaruhi perkembangan kematangan emosi anak remaja (secara positif atau negatif). Namun demikian, jika melihat hasil korelasi antara pola asuh otoriter ayah dan ibu yang signifikan, maka hal ini mendorong untuk dilakukan analisa tambahan yaitu melihat pola asuh otoriter ayah, pola asuh otoriter ibu, dan kesabaran sebagai tiga variabel independen untuk melihat pengaruhnya terhadap kematangan emosi anak remaja. 
Tabel 2

Analisa Moderator

\begin{tabular}{lllll}
\hline Prediktor & B & SE B & $\boldsymbol{\beta}$ & $\mathbf{R}^{2}$ \\
\hline Variabel Dependen: Kematangan Emosi & & & & \\
\hline Ayah & & & & \\
Step 1 & & & & \\
PAO Ayah_MC & -0.140 & 0.069 & $-.0 .132^{*}$ & $0.179^{* * *}$ \\
KK_MC & 0.522 & 0.083 & $0.405^{* * *}$ & \\
Step 2 & & & & \\
PAO Ayah_MC & -0.140 & 0.069 & $-.0 .132^{*}$ & $0.179^{* * *}$ \\
KK_MC & 0.522 & 0.083 & $0.405^{* * *}$ & \\
KK_MC x PAO Ayah_MC & 0.001 & 0.009 & 0.009 & \\
Ibu & & & & \\
Step 1 & & & & \\
PAO Ibu_MC & 0.008 & 0.072 & 0.008 & $0.162^{* * *}$ \\
KK_MC & 0.519 & 0.084 & $0.402^{* * *}$ & \\
Step 2 & & & & \\
PAO Ibu_MC & 0.009 & 0.072 & 0.008 & $0.162^{* * * *}$ \\
KK_MC & 0.518 & 0.085 & $0.402^{* * *}$ & \\
KK_MC x PAO Ibu_MC & 0.000 & 0.10 & -0.002 & \\
\hline Catatan: & & & & \\
\end{tabular}

Catatan:

- $* * * \alpha<0.001, * * \alpha<0.01, * \alpha<0.05$

- PAO: Pola Asuh Otoriter, KK: Kompetensi Kesabatan, SE: Standar Error, MC: Mean Centered

Berdasarkan hasil analisis data dengan melihat ketiga konsep tersebut sebagai variable yang independen, ditemukan bahwa bahwa pola asuh otoriter ayah, pola asuh otoriter ibu, dan kesabaran terbukti secara signifikan mempengaruhi perkembangan kematangan emosi anak remaja. Ketiganya secara bersama-sama memberi sumbangan secara signifikan terhadap kematangan emosi anak remaja. Pola asuh otoriter ayah memberi pengaruh negatif terhadap kematangan emosi, sedangkan pola asuh otoriter ibu dan kesabaran memberi pengaruh positif terhadap kematangan emosi anak. Pola asuh otoriter ibu memberi sumbangan positif terhadap kematangan emosi anak dengan $\mathrm{B}=0.157 \quad(\alpha<0.1)$. Kesabaran memberi sumbangan positif terhadap kematangan emosi dengan
$\mathrm{B}=0.536(\alpha<0.001)$. Sebaliknya, pola asuh otoriter ayah memberi sumbangan negatif terhadap kematangan emosi dengan $\mathrm{B}=$ $0.233(\alpha<0.01)$.

Berdasarkan hal analisa ini maka dapat dibuat rumusan untuk memprediksi tingkat kematangan emosi secara signifikan $\left(\mathrm{R}^{2}=0.192, \quad \mathrm{~F}=15.475, \quad \alpha<0.001\right) . \quad$ Hasil analisa ini dapat dilihat pada tabel 3. Adapun rumus untuk mengukur kematangan emosi berdasarkan hasil analisa ini adalah: $\mathrm{KE}=$ $38.845+0.536 \mathrm{KK}+0.157 \mathrm{PAO} \mathrm{Ibu}-0.233$ PAO Ayah 
Tabel 3

Analisa Moderator

\begin{tabular}{llllll}
\hline \multicolumn{1}{c}{ Prediktor } & B & SE B & \multicolumn{1}{c}{$\boldsymbol{\beta}$} & \multicolumn{1}{c}{$\mathbf{R}^{\mathbf{2}}$} & \multicolumn{1}{c}{ F } \\
\hline Variabel Dependen: & & & & & \\
Kematangan Emosi & & & & & \\
Konstanta & 38.845 & 6.966 & $* * *$ & $0.192^{* * *}$ & 15.475 \\
PAO Ibu & 0.157 & 0.90 & $0.142^{+}$ & & \\
PAO Ayah & -0.233 & 0.87 & $-0.219^{* *}$ & & \\
KK & 0.536 & 0.83 & $0.416^{* * *}$ & & \\
\hline
\end{tabular}

Catatan:

- ${ }^{* * *} \alpha<0.001,{ }^{* *} \alpha<0.01, * \alpha<0.05,{ }^{+} \alpha<0.1$

- PAO: Pola Asuh Otoriter, KK: Kompetensi Kesabatan, SE: Standar Error, MC: Mean Centered

Hasil analisa tambahan ini dapat menjelaskan secara lebih rinci bagaimana pengaruh pola asuh otoriter orang tua terhadap perkembangan anak. Kesabaran dapat turut meningkatkan kematangan emosi bersama-sama dengan pola asuh otoriter ibu. Disaat yang sama, pola asuh ayah akan mereduksi kematangan emosi anak remaja.

Jika mengacu pada penelitian Steinberg, dkk. (1994), hasil penelitian ini dapat menjelaskan secara lebih rinci bagaimana relevansi pola asuh otoriter terhadap perkembangan anak. Berdasarkan penelitian ini, Pola asuh otoriter dapat memberikan pengaruh secara relatif terhadap kematangan emosi. Pola asuh otoriter dari ibu dapat memberi dampak yang positif dan sebaliknya pola asuh otoriter dari ayah akan memberi dampak yang negatif bagi kematangan emosi.

Berbanding terbaliknya pengaruh pola asuh otoriter ayah dan ibu, kemungkinan dikarenakan budaya Indonesia terkait dengan pola asuh tersebut. Hubungan ayah dan anak yang umumnya tidak terlalu dekat dibanding hubungan anak dengan ibu dapat menjadi salah satu faktor penyebabnya (Elia, 2000). Intensitas interaksi anak yang lebih tinggi dengan ibu pada kultur Indonesia dapat menjadi salah satu faktor bagi anak untuk bisa menilai pola asuh otoriter yang diterapkan oleh ibu menjadi lebih positif.

Begitu juga jika kita melihat hasil penelitian Chao (1994) di China yang menunjukkan bahwa pola asuh otoriter yang dijalankan di China memberi dampak positif bagi perkembangan anak karena berdasarkan penelitian tersebut penanaman idologi merupakan faktor yang sangat penting dalam membentuk karakter positif anak dan harus dilakukan dengan model yang otoriter. Penelitian ini dapat menjelaskan secara lebih detail pada bagianbagian yang menyebabkan pola asuh otoriter berdampak positif atau berdampak negatif pada perkembangan anak. Budaya Indonesia dimana ada pembagian peran pengasuhan ayah dan ibu terhadap anak dapat menjadi pembeda dampak yang dirasakan oleh anak.

Berdasarkan perbedaan tersebut dapat dimungkinkan pola asuh yang dijalankan ibu yang umumnya lebih permisif dan hasil penelitian ini menunjukkan bahwa ibu perlu lebih tegas dalam pola asuhnya. Sebaliknya pola asuh ayah mungkin terlalu otoriter dimana ayah umumnya mengambil peran sebagai penegak aturan maka pola asuh tersebut perlu dikendurkan agar tidak memberi dampak negatif. Dengan demikian, kerjasama antar kedua orangtua untuk saling 
melengkapi pola pengasuhan masing-masing menjadi penting dalam perkembangan anak.

\section{Simpulan}

Berdasarkan hasil penelitian, dapat disimpulkan bahwa kesabaran tidak berperan sebagai variabel moderator antara pola asuh otoriter dengan kematangan emosi namun memberikan pengaruh yang signifikan bersama pola asuh otoriter orangtua terhadap kematangan emosi. Hasil penelitian juga menunjukkan bahwa pola asuh otoriter tidak selalu berdampak negatif bagi perkembangan kematangan emosi anak. Pola asuh otoriter dapat menjadi pola asuh yang bermanfaat bagi kematangan emosi anak apabila pola asuh tersebut diterapkan oleh ibu dan sebaliknya jika diterapkan oleh ayah apabila diterapkan secara bersama-sama. Kesabaran anak dapat membantu untuk mengatasi dampak negatif dari pola asuh otoriter ayah dan disaat yang sama menguatkan pola asuh otoriter ibu. Berdasarkan penelitian ini maka pola asuh otoriter dari ibu tidak perlu dianggap sebagai sesuatu yang berbahaya bagi perkembangan anak karena pola asuh ini terbukti memberi manfaat positif terhadap kematangan emosi anak remaja jika diterapkan oleh ibu. Sebaliknya, jika pola asuh itu diterapkan oleh ayah maka perlu didukung dengan kesabaran anak dan pola asuh yang juga otoriter dari ibu. Orang tua tetap perlu melatihkan kemampuan sabar pada anak agar dampak negatif dari pola asuh otoriter dapat dihindari dan diperoleh dampak positif dari pola asuh otoriter tersebut. Meskipun demikian, diperlukan kajian lain untuk membuktikan peran dari intensitas interaksi kesabaran sebagai variabel moderator dari pola asuh otoriter orang tua. Intensitas interaksi dapat menyebabkan pola kelekatan tertentu atau pola ketergantungan tertentu dari anak pada orangtuanya.

\section{Daftar Pustaka}

Ayuningtyas, D. (2013). Orientasi Pola Pengasuhan Anak Usia Dini Pada Keluarga Militer di Asrama Kodam Kelurahan Jatingaleh Candisari Semarang. Indonesian Journal of Early Childhood Education Studies, 2(1), 1-7.

Baumrind, D. (1966). Effects of authoritative parental control on child behavior. Child development, 37 (4) 887-907.

Baumrind, D. (1968). Authoritarian vs. authoritative parental control. Adolescence, 3(11), 255-272

Baumrind, D. (1991). Effective parenting during the early adolescent transition. Family transitions (ed. Cowan \& Hetherington), 2, 111-163.

Baumrind, D. (1991). The influence of parenting style on adolescent competence and substance use. The Journal of Early Adolescence, 11(1), 56-95.

Blissett, J., \& Haycraft, E. (2008). Are parenting style and controlling feeding practices related?. Appetite, 50(2), 477-485.

Buri, J. R. (1991). Parental authority questionnaire. Journal of personality assessment, 57(1), 110-119.

Chao, R. K. (1994). Beyond parental control and authoritarian parenting style: Understanding Chinese parenting through the cultural notion of training. Child development, 65(4), 1111-1119.

Chao, R. K. (2000). The parenting of immigrant Chinese and European 
American mothers: Relations between parenting styles, socialization goals, and parental practices. Journal of Applied Developmental Psychology, 21(2), 233-248.

Chao, R. K. (2001). Extending research on the consequences of parenting style for Chinese Americans and European Americans. Child development, 72(6), 1832-1843.

Darling, N., \& Steinberg, L. (1993). Parenting style as context: An integrative model. Psychological bulletin, 113(3), 487.

Dudley, K. C. (2003). Empirical development of a scale of patience. Doctoral Dissertation. West Virginia University

El Hafiz, S., Munszir, I., Pratiwi, L., Rozi, F. (2013). Sabar (Patience) as New Psychological Construct in The 10th Biennial Conference of Asian Association of Social Psychology, Yogyakarta, August 21 -24.

Elia, H. (2000). Peran ayah dalam mendidik anak. Veritas, 1, 105-113.

Kapri, U. C., \& Rani, N. (2014). Emotional Maturity: Characteristics and Levels. International Journal of Technological Exploration and Learning (IJTEL), 3(1), 359-361.

Licht, C., \& Chabot, D. (2006). The Chabot Emotional Differentiation Scale: A theoretically and psychometrically sound instrument for measuring Bowen's intrapsychic aspect of differentiation. Journal of marital and family therapy, 32(2), 167-180.

Nisbett, R. E., Peng, K., Choi, I., \& Norenzayan, A. (2001). Culture and systems of thought: holistic versus analytic cognition. Psychological review, 108(2), 291.

Pratiwi, L., \& El Hafiz, S. (2015). Metode "Analisa Tafsir" dalam Rangka Membangun Teori Psikologi dari Integrasi Epistemologi. Jurnal Ilmiah Penelitian Psikologi: Kajian Empiris \& Non-Empiris, 1(1). H. 57-63

Schnitker, S. A. (2010). An examination of patience and well-being. Doctoral Dissertation. University of California

Schwartz, S. H. (2006). A theory of cultural value orientations: Explication and applications. Comparative sociology, 5(2), 137-182.

Steinberg, L., Lamborn, S. D., Darling, N., Mounts, N. S., \& Dornbusch, S. M. (1994). Over-time changes in adjustment and competence among adolescents from authoritative, authoritarian, indulgent, and neglectful families. Child development, 65(3), 754-770. 